\title{
TOURISM IN THE ELECTORAL PROGRAMS OF TURKISH POLITICAL PARTIES: AN ANALYSIS OF THE 2015 GENERAL ELECTIONS IN TURKEY
}

\author{
Asistant Prof., Mustafa YILDIRIM \\ Alanya Alaaddin Keykubat University, Faculty of Management (mustafayildirimdr@gmail.com) \\ Asistant Prof., Özhan DEMIRKOL \\ Ömer Halisdemir University, Faculty of Economics and Administrative Sciences, (ozhandem@gmail.com) \\ Prelector, Lütfiye YILDIRIM \\ Alanya Alaaddin Keykubat University, ALTSO Tourism Vocational School, (lutfiyekasyildirim@gmail.com) \\ Prelector, Cansu SOLMAZ \\ Aksaray University, Berat Cömertoğlu Vocational School,(cansusolmaz@aksaray.edu.tr)
}

\begin{abstract}
Political parties are indispensable elements of democratic systems. In addition to their functions of interest articulation and aggregation, they play a key role in the preparation of policies for different sectors, including tourism. This work analyzes electoral programs of the four parties that passed the 10\% national threshold in the two Turkish elections, which took place in 2015 and reveals their promises and policy suggestions. The analysis suggest that the major Turkish political parties promise to sustain economic development, improve education and service standards, diversify alternative tourism products and maintain ecological sustainability in touristic regions.
\end{abstract}

Keywords: Political Parties, Electoral Programs, Strategic Tourism Management.

\section{SIYYASI PARTILERIN SEÇIM BEYANNAMELERINDE TURIZM: 2015 GENEL SEÇIMLERİ ÜZERINE BİR İNCELEME}

\section{ÖZET}

Siyasi partiler, demokratik yönetimleri önemli kurumlardan biridir. Ürettikleri politika, plan ve projeler ile her alanda olduğu gibi turizm sektörünün mevcut ve gelecekteki durumu açısından da önemli bir konuma sahiptir. Bu çalışmada Türkiye'de 2015 yılında gerçekleştirilen genel seçimlere katılan 20 siyasi partiden \%10 barajını geçerek mecliste temsil hakkı elde etmiş dört siyasi partinin seçim beyannamesi incelenmiş ve turizm konusunda, partilerce verilen vaatler ve önerilen politikalar belirlenmeye çalışılmıştır. İncelemeye göre, partilerin turizm bağlamında üzerinde durdukları ana konular; ekonomik kalkınmanın sağlanması, eğitim ve hizmet kalitesinin yükseltilmesi, alternatif turizm çeşitlerinin ve özellikle să̆lık turizminin geliştirilmesi, turizmin bölgelerinin ekolojik sürdürülebilirliğinin să̆lanması olmuştur.

Anahtar Kelimeler: Siyasi Parti, Seçim Beyannamesi, Stratejik Turizm Yönetimi. 


\section{Introduction}

Political parties are indispensable elements of democratic life. Not only in the advanced democracies of the Western World, but also in the second and third wave democracies, parties play a key role in the determination and realization of public policies. In parliamentary democracies with high levels of party discipline, parliamentary groups of the political parties are the primary mechanisms behind the policy proposals. Although the bureaucracy and the pressure groups play an influential role in policy-making process, the final decisions are made by the parliamentary groups. In other words, political parties are one of the most important actors in policy-making process.

One of the most important functions of political parties is to initiate policy proposals on behalf of the voters. Voters are inclined to delegate their authority due to factors such as lack of spare time and knowledge or their disinterest in politics. With their expertise in political matters, political parties initiate policy proposals, and demand the voter support in return (Strom \& Müller, 2009:33). In other words, political parties structure the issues and aggregate conflicting interests into a single program (Gunther \& Diamond, 2001:8). These activities find their place in electoral manifestos and the programs of political parties.

Analysis of the electoral programs of political parties provide us with important clues about the potential policy initiatives about different fields, including economy, education, health, social security or international relations (Biçer \& Y1lmaz, 2009). Various scholars analyzed the political parties' electoral programs in order to reveal the parties' policy positions (Stratejik Düşünce Enstitüsü, 2011; Oğurlu, 2011; Gönenç, 2011; Tok, 2012; Kilit \& Çatır, 2015; İKSV, 2015). The analysis of the major parties' promises stated in their electoral manifestos may provide us with the clues about the future policy proposals that may be initiated following the elections. Even the tourism plans and policies, which are commonly developed by the bureaucracy are bounded by the promises of the political parties in democratic regimes. In other words, the development of the tourism plans are not only shaped by the bureaucracy, but also the ideological priorities of the political parties (McLeod \& Airey, 2007:5).

The future of tourism in especially the developing countries is shaped by the government programs (Chambers \& Airey, 2001:118), which are crucial for regional tourism development (Hall, 2010:3). In this sense, electoral programs proposed by the competing political parties may constitute a crucial resource to assess the future development and planning of the tourism sector. However, the review of the relevant literature reveals the lack of interest in political parties during the policy-making process. The vast majority of the works on Turkish tourism planning deal with the five-year development plans (Çavuş et al., 2009; Demir, 2014), promotion of tourism (Toker, 2007) or the governmental policies on tourism sector (Esen et al., 2012). Only a few works deal with the political parties' stances towards the tourism sector (Yüksel et al., 2009; Yüksel et al., 2009; Gürbüz et al., 2014). We believe that further research on this problem should be carried out.

The aim of this study is to reveal the position of the Turkish political parties towards the tourism sector. In order to realize this aim, the study analyzes the electoral programs of the major Turkish political parties that competed in the two general elections held on June 
and November, 2015. The analysis centers on the policy positions, promises and priorities of the Turkish political parties regarding the tourism sector, and their approaches towards the social, cultural, ecological and economic dimensions of the tourism sector. We believe that the analysis will provide an important contribution to the literature by revealing the political parties' approach to the tourism sector in a comparative way.

\section{General Evaluation of Turkish Tourism Policies}

Tourism is an important sector with its potential contributions to the economies of the developing countries. In case of mismanagement, the development of tourism may result with social, cultural or environmental problems. Due to this, preparation and realization of long-term tourism plans that will maximize the benefits and minimize the side effects of the development tourism sector are highly important. (Sözen, 2006:12).

Tourism policies are determined by taking the primary aim and various factors into consideration. They should be in line with the policies developed for sectors that are related with the tourism sector. (Inskeep, 1991:170). This is due to the fact that the tourism sector, which is in relationship with various economic sectors cannot be developed properly in an unplanned manner (Sarkım, 2008:6). In other words, the development of tourism and its economic, cultural and social impacts depends on the success of the tourism plan and policies (Dredge \& Jamal, 2015:285).

Table 1: Primary Aims of the Five-Year Development Plans in Turkey (1963-2013)

\begin{tabular}{|c|c|}
\hline $\begin{array}{l}\text { Five-Year } \\
\text { Development Plans }\end{array}$ & Primary aims \\
\hline $\begin{array}{l}1^{\text {st }} \text { Development } \\
\text { Plan ( 1963) }\end{array}$ & $\begin{array}{l}\text { Improvement of touristic demand; promotion } \\
\text { of tourism investments }\end{array}$ \\
\hline $\begin{array}{l}2^{\text {nd }} \text { Development } \\
\text { Plan (1968) }\end{array}$ & $\begin{array}{l}\text { Organization of the Ministry of Tourism } \\
\text { and Promotion; cooperation with the } \\
\text { Mediterranean countries; improvement of } \\
\text { tourism education. }\end{array}$ \\
\hline $\begin{array}{l}3^{\text {rd }} \text { Development } \\
\text { Plan (1973) }\end{array}$ & $\begin{array}{l}\text { Revitalization of social and domestic tourism; } \\
\text { improvement of tourism education }\end{array}$ \\
\hline $\begin{array}{l}4^{\text {th }} \text { Development } \\
\text { Plan (1979) }\end{array}$ & $\begin{array}{l}\text { Improvement of mass tourism; improvements } \\
\text { in infrastructure in line with the demands } \\
\text { of the tourism sector; promotion of foreign } \\
\text { investment }\end{array}$ \\
\hline $\begin{array}{l}5^{\text {th }} \text { Development } \\
\text { Plan }(1985)\end{array}$ & $\begin{array}{l}\text { Improvement of the touristic relations with } \\
\text { the OECD, OPEC, Balkan states and the third } \\
\text { world countries; improvement of the tourism } \\
\text { demand in the fields of social tourism, winter } \\
\text { tourism, hunting, watersports, festival, health } \\
\text { and youth; promoting four-season tourism }\end{array}$ \\
\hline
\end{tabular}


Table 1 continued

\begin{tabular}{|c|c|}
\hline $\begin{array}{l}6^{\text {th }} \text { Development } \\
\text { Plan (1990) }\end{array}$ & $\begin{array}{l}\text { Development of tourism in the fields of } \\
\text { winter, watersports, festivals, health sector, } \\
\text { youth, congress, thermal and golf tourism; } \\
\text { promotion of the third age tourism; education } \\
\text { of qualified labor force }\end{array}$ \\
\hline $\begin{array}{l}7^{\text {th }} \text { Development } \\
\text { Plan (1996) }\end{array}$ & $\begin{array}{l}\text { Protection of natural heritage; balancing the } \\
\text { spatial and temporal distribution of tourism; } \\
\text { diversification and improvement of touristic } \\
\text { products in line with changing tourism } \\
\text { demands and trends; improvements in } \\
\text { tourism education; transition to professional } \\
\text { documentation system }\end{array}$ \\
\hline $\begin{array}{l}8^{\text {th }} \text { Development } \\
\text { Plan (2001) }\end{array}$ & $\begin{array}{l}\text { Diversification of alternative tourism } \\
\text { types; overcoming seasonality and regional } \\
\text { concentration; promotion of sustainable } \\
\text { tourism approach; involvement of local } \\
\text { stakeholders in tourism plans and policies; } \\
\text { improvement of tourism education and } \\
\text { service quality; transition to professional } \\
\text { documentation system }\end{array}$ \\
\hline $\begin{array}{l}9^{\text {th }} \text { Development } \\
\text { Plan (2007) }\end{array}$ & $\begin{array}{l}\text { Diversification of touristic products; } \\
\text { improvements in service quality; protection } \\
\text { of natural and historical heritage; promotion } \\
\text { of health tourism }\end{array}$ \\
\hline $\begin{array}{l}1^{\text {th }} \text { Development } \\
\text { Plan (2013) }\end{array}$ & $\begin{array}{l}\text { Turning into an international brand with } \\
\text { qualified labor force, facilities and services; } \\
\text { evaluation of the touristic product potential } \\
\text { that will attract upper-income groups; turning } \\
\text { the tourism into a leading regional sector; } \\
\text { development of alternative touristic activities; } \\
\text { promotion of health tourism; maintaining } \\
\text { the socio-cultural, economic and ecological } \\
\text { sustainability. }\end{array}$ \\
\hline
\end{tabular}

Turkish tourism policies have been generally divided into two time periods: preplanned period (1923-1962) and the planned period (1963- ) (Ege, 2009). The focus on tourism has started with the transition to a planned economic development. Until 2013, the State Planning Agency prepared 10 five-year development plans, which provided aims and strategies for the development of the tourism sector (DPT, 2015). Table 1 shows the primary aims stated in these development plans. The table reveals that the Turkish tourism plans have dealt with issues such as tourism demand, investments, education, international cooperation, sectoral administration, alternative tourism, and socio-cultural, economic and ecological sustainability. 
In addition to the five-year development plans, an action plan was proposed by the Ministry of Culture and Tourism in 2007 entitled "Tourism Strategy of Turkey-2023". The vision of the strategy document is read "with the adaptation of sustainable tourism approach, tourism and travel industry will be brought to a leading position for leveraging rates of employment and regional development and it will be ensured that Turkey becomes a world brand in tourism and a major destination in the list of the top five countries receiving the highest number of tourist and highest tourism revenues by 2023" (Ministry of Culture and Tourism 2007:4). In line with the vision, the strategy document proposes a number of goals and actions in the fields of education, employment, economic and regional development, sustainability and touristic products, which are planned to be reached until 2023.

\section{Aims and Methods}

The primary aim of this study is to reveal the policy promises and the approaches of the major Turkish political parties towards the tourism sector. With this aim in mind, we conduct content analysis and use the electoral manifestos of the Turkish political parties that have participated in the two general elections, which took place on June 7 and November 1, 2015. The promises and the policies of the Turkish political parties on tourism sector have been categorized within the context of the "Sustainable Tourism Targets" prepared by the United Nations Environment Program and dealt by the $10^{\text {th }}$ Development Plan Tourism Special Expertise (Ministry of Development 2014). These promises have been categorized into 12 dimensions. The findings on the attitudes of the political parties towards tourism are discussed within the context of the development plans and the 2023 tourism strategy.

The 7 June elections ended with the victory of The Justice and Development Party (Adalet ve Kalkınma Partisi- Ak Parti), which won $40.86 \%$ of the votes. The Ak Party was followed by three parties that passed the $10 \%$ national threshold, namely the Republican People's Party (Cumhuriyet Halk Partisi-CHP), the Nationalist Action Party (Milliyetçi Hareket Partisi- MHP) and the Peoples' Democratic Party (Halkların Demokratik Partisi- HDP), which received $24,94 \%, 16,28 \%$ and $13.11 \%$ of the votes, respectively. The rest of the parties, which did not pass the national threshold received $4.81 \%$ of the votes in total. Since none of the parties reached to an agreement to form the government, the national elections were held on November 1, 2015. During the second general elections, 29 parties competed and only the four parties mentioned above passed the national threshold. The Ak Party came the first with $49.48 \%$ of the votes. The remaining three opposition parties, namely the CHP, the MHP and the HDP won 25, $31 \%, 11,90 \%$ and $10,75 \%$ of the votes, respectively. The remaining minority parties received $2.56 \%$ of the total percentage of votes. This study focuses on the relevant parties, which passed the $10 \%$ national threshold to be represented in the assembly. Therefore, our analysis will specifically focus on the electoral manifestos of the Ak Party, the CHP, the MHP and the HDP.

\section{Findings}

This part deals with the analysis of the plans, policies and attitudes of the political parties towards the tourism sector, as indicated in their electoral manifestos. 


\subsection{Justice and Development Party (Ak Party)}

The electoral manifesto of the Ak Party prepared for the 7 June election comprises 386 pages and 66.507 words. The word 'tourism' is mentioned 105 times and the party allocated 6 pages specifically dealing with tourism. The part on tourism sector is included under the heading, entitled "stable and strong economy". The analysis of the part shows that tourism is not considered only as an economic sector but is perceived as a component of foreign affairs and cultural dialogue (AK Party, 2015a:232).

As the ruling party of the country since 2002, the Ak Party has the chance to underline the contributions of the Ak Party governments to the tourism sector. The party used this advantage in 7 June 2015 elections and placed special emphasis to its prior performance on tourism sector. Consequently, the party dealt with the developments in Turkish tourism under the heading of "what we did?". In this part, the party deals with the increase in the number of foreign tourists, hotels, travel agencies and tourism receipts. Besides, the party deals with the actual measures taken during the Ak Party governments, including the structural, administrative and economic incentives for hotel enterprises, enactment of the law on professional tourist guiding, formation of the Gallipoli Wars Gallipoli Historical Site Presidency, preparation of the Tourism Strategy of Turkey-2023, introduction of the certification system, and improvement in the assignment conditions of the thermal and winter tourism investments. Besides, the Ak Party electoral program states that the conversion programs of health tourism were introduced in order to diversify tourism sector and that the enterprises operating in health tourism were granted benefits such as access to market, certification, consultation and the incentives to encourage trade and purchase missions. About the development of tourism in Eastern Black Sea region, the manifesto states that the Eastern Black Sea Tourism Master Plan was introduced to promote plateau tourism and new tour routes. Regarding the promotion activities, the manifesto states that promotions were conducted in 87 countries with 37 different languages and that the concept of "Turkey: Home” was used for promotion activities (Ak Party, 2015a:232-234).

In addition to the prior performance of the Ak Party governments, the Ak Party election manifesto deals with the party's promises under the title "What will we do?" The primary emphasis is made on the promotion of the alternative destinations, routes and tourism types, including health, thermal winter, plateau, convention and golf tourism (Ak Party, 2015a:235). Additionally, the Ak Party promises to develop more attractive and important alternative destinations and routes by integrating the places, which have been promoted as single destinations, including the places that are important in terms of health, thermal, plateau, winter and cultural tourism types (Ak Party, 2015a: 235). In order to make the tourism plan and policies more efficient, the party declares that the distribution of the public investments will take the point of destination management into consideration. In order to maintain this goal, the party undertakes to decrease the bureaucratic barriers for tourism centers and to develop new 'Area Management Models' that will facilitate capital inflow (Ak Party, 2015a:235)

The Ak Party electoral manifesto also deals about the party's promises for ecotourism, rural tourism and agro-tourism within the context of sustainable tourism development. Accordingly, the party promises to conduct activities that will increase awareness on these tourism types. The party also declared to take necessary measures to increase the number of 
green star-certificated tourism enterprises (Ak Party, 2015a: 235). Making reference to the 2023 tourism strategy paper, the Ak Party promises to develop nine tourism development zones, seven thematic tourism corridors, ten tourism cities and five ecotourism zones. Furthermore, the Ak Party declares that the Winter Tourism Master Plan and a special strategy paper for winter tourism in Eastern Turkey will be prepared (Ak Party, 2015a:235-236). Regarding the Eastern Black Sea Region, the party states that the 'Green Voyage' concept will be promoted, the construction of the 'Green Road' that connects the plateaus of eight provinces will be continued, and the accommodation infrastructure will be developed in order to diversify tourism types. In order to contribute to the development of yacht tourism, the Ak Party promises to complete Demre, Aydıncık, Yeni Foça and Turan marinas (Ak Party, 2015a:236). Regarding the Southeastern Turkey, the Ak Party manifesto states that the Ak Party governments spent 274 million TL for the tourism programs in Diyarbakır, Erzurum, Gaziantep, Şanlıurfa and Van, which prioritized the development of culture tourism in the region. The Ak Party manifesto states the increase in the number of visitors and the average spending per visitor, extension of the tourism season throughout the year and balanced distribution of the domestic and foreign demand to all regions as the targets of the party. Regarding the promotion, the party promises to take necessary measures by taking the changes in tourism market and the customer profile into account, to brand tourism zones in order to increase competitive power and to introduce a holistic approach to the promotion of historical, cultural and touristic values in order to empower the country's image. In terms of education, the Ak Party states that party will complete the sectoral employment research and to make necessary changes in tourism education in order to fulfill the demands of tourism sector (Ak Party, 2015a:236).

Projects about health tourism are promising in the electoral manifesto of the Ak Party. The Ak Party promises to increase competitive advantage of the country by using the 'Health Tourism Improvement Program', which was prepared to improve medical, thermal and health tourism and service quality for elderly and the disabled people. Within this context, the party promises to establish 100.000 bed capacity in health tourism, to supply service to 1.500 .000 (600.000 treatment purposes) foreign tourists in thermal tourism, to obtain 3 billion dollars in thermal tourism, to provide medical treatment to 750.000 foreign patients, to obtain 5.6 billion dollars revenue in medical tourism, and to be among 5 global destinations in medical tourism. The party targets to serve 150.000 elderly foreign tourists and to obtain 750 million dollars revenue in this tourism segment. The Ak Party manifesto states that a 'Health Tourism Coordination Council' will be established to follow the developments in the sector, necessary legal amendments will be made, foreign student quota in medical faculties will be increased, necessary qualifications of health personnel, including foreign language, will be increased, and, promotion and marketing activities in the target countries and zones will be enhanced (Ak Party, 2015a:236). Finally, the Ak Party states that environment is the most important component of the tourism policy. In order to protect environment, the party promises to implement sustainable environment policies in order to support the development of tourism in a sustainable manner, and to take necessary measures to eliminate the negative impacts of tourism over environment (Ak Party, 2015a:235).

In addition to the section on tourism, the tourism sector is dealt in different sections, including health, culture, sport, rural and national development, social welfare, transportation, 
education, local governance, environment and promotion. Besides, the party states that tourism can be used as a tool for lobbying activities in foreign relations and promotion activities. The party did not make any changes in the next elections held on November 1, 2015 (Ak Party, 2015b).

\subsection{Republican People's Party (CHP)}

The CHP, which received $29.94 \%$ of the votes in 7 June elections published an electoral program that consists of 203 pages. The party prepared a special section on tourism, which consists of 2 pages, and the term tourism was mentioned 34 times in the manifesto of the CHP. The part on tourism sector consists of five subheadings, namely sustainable tourism strategy, diversification of tourism, qualified labor force, legal amendments and environment-friendly tourism.

The CHP promises to promote a sustainable tourism sector, to support the national tour operators, to increase competitive power of the sector by using the strategy of branding and to promote all tourism regions under the heading of 'sustainable tourism strategy'. Regarding the diversification of touristic activities, the CHP undertakes to support alternative tourism types and promises to increase the potential of winter tourism, to place special emphasis on festival, expo and congress tourism and to promote the construction of enterprises in the fields of thermal, hydrotherapy and health tourism. Under the 'qualified labor force' heading, the CHP states that tourism education will be given special importance, tourism education will be arranged according to the needs of the tourism sector, insurance premiums will be lowered in low seasons, and concrete projects to employ the graduates of tourism schools will be formed.

Regarding the legal amendments, the CHP promises to amend the laws on travel agencies, to transfer the right to audit the travel agencies to Association of Turkish Travel Agencies (TÜRSAB), to give the travel agencies the authority to manage the hajj and umrah visits under the supervision of the Directorate of Religious Affairs, and to introduce gradual holidays for schools in order to overcome the seasonality problem. The CHP places also special emphasis on the issue of environment under the heading of 'environment-friendly tourism'. The party states that environmental concerns will be taken into consideration during the preparation of the zoning plans of the coastal sites and the environmental impact assessment reports will be based on scientific concerns (CHP, 2015a:59-60).

In addition to these issues, the CHP electoral manifesto deals with the issue of social tourism. The party targets to provide the elderly people low-cost tourism activities (CHP, 2015a:59-60). Furthermore, the party promises to construct sports facilities at global standards in order to promote Turkey (CHP, 2015a:137), to encourage the touristic development of Ankara as the capital of culture and arts (CHP, 2015a:137), to separate the Culture and Tourism Ministry into two ministries (CHP, 2015a:131), to improve transportation infrastructure in Southeast Project (GAP) region and to support sustainable tourism in the GAP region (CHP, 2015a:140).

In its electoral program, the CHP places special emphasis on Izmir, a province in which the CHP has traditionally been strong since the 2002 elections. The party promises to diversify tourism in Izmir, to extend tourism in Izmir throughout the year in order to make the city a 
lively place, to connect Selçuk and Bergama, two important historical sites, to Izmir airport via rail system and to turn Izmir into a global health tourism center so that it can serve 1 million patients and receive at least $10 \%$ of the global revenue spent for health tourism (CHP, 2015a:140).

Another point that deserves attention in the electoral program of the CHP is the party's argument that tourism can be used to form and develop international strategic relations. For instance, the CHP states that tourism can be used to improve economic relations with Iran (CHP, 2015a:188), promises to establish a mechanism to maintain contact and cooperation among the local governments, civil society organizations and the enterprises of Russia and Turkey in order to promote tourism sector (CHP, 2015a:188), and undertakes to develop touristic and cultural relations with the African countries, particularly those in Northern Africa (CHP, 2015a:190).

The analysis of CHP electoral manifesto reveals that the party resembles to the Ak Party in its approach to tourism. The CHP considers tourism as a sector that is closely linked with sustainable economy, competitive power, education, employment, rural development, social development, health, culture, history and sports. Besides, similar to the Ak Party, the CHP acknowledges the contributions of tourism for foreign affairs and sustainable development. Finally, similar to the Ak Party, the CHP did not make any changes in its promises on tourism in the electoral program prepared for the second election on November 2015 (CHP, 2015b).

\subsection{Nationalist Action Party (MHP)}

The electoral manifesto of the MHP, which received 16, $28 \%$ of the votes in 7 June elections, consisted of 257 pages and 43.739 words. The party allocated a special section for the tourism sector and the term 'tourism' was used 50 times in the electoral program. The tourism section of the MHP program consisted of six subheadings: enactment of the environment law, protection of uniqueness, four-season tourism, diversification of customers, promotion of alternative tourism values and development of health tourism.

The first section on enactment of environment law deals with the party's promises to solve sectoral problems through the use of legal tools. In this part, the party promises to enact a 'Tourism Framework Law', which will include changes in tourism promotion law, labor law, coastal law and other laws about the sector. The MHP manifesto states that a new tourism strategy paper and action plan will be prepared by the joint efforts of the public and private sector and that the Ministry of Culture and Tourism will be restructured. Under the 'uniqueness of Turkish tourism will be protected' subheading, the MHP states that during the use of natural, historical, cultural and other values of Turkey, environment, history and uniqueness will be protected and sustainability will be concerned. Under the next heading, entitled 'four-season tourism potential will be realized', the party promises to extent tourism throughout the four seasons by using promotion and marketing strategies, to establish coordination and cooperation between public and private sector and to empower the local tradesmen in order to protect local economy (MHP, 2015a:226). Under the 'we will diversify customers' heading, the MHP promises to implement a new tourism policy that prioritizes new markets and a new image of Turkey and that calls for the cooperation and harmony between public and the private sectors. The party also states that the demands of the customers, particularly the high-income groups, 
will be taken into consideration to develop tourism; the historical sites will be protected and restored; the historical, cultural and environmental characteristics of the touristic sites will be protected during the preparation of the zoning plans; and, qualified labor force will be increased to maintain high quality service. The next heading, entitled "alternative tourism richness will be maintained", deals with the promises of the MHP, such as improvement of alternative tourism zones, research on geological heritage, promotion of geoparks, ecotourism and geotourism, and increase in the share of revenues obtained from the global tourism market through the use of promotion and marketing activities (MHP, 2015a:227). The final subheading, entitled "health tourism will become widespread", includes the party's plans, including the establishment of 'Free Health Zones' to increase health tourism revenues, free allocation of public property to the enterprises on health tourism, and public support to cooperation between the foreign and domestic health tourism enterprises in order to increase foreign direct investment (MHP, 2015a:228).

The analysis of the MHP electoral manifesto shows that the party considered tourism together with concepts such as conservation of the historical, cultural and social values, extension of tourism throughout the year, diversification of consumers to target high-income groups, labor quality, and health tourism. The party received $11.90 \%$ of the votes in the elections held on November 1 and did not make any changes on its electoral manifesto (MHP, 2015b).

\subsection{Peoples' Democratic Party (HDP)}

The HDP, which received $13.11 \%$ of the votes in 7 June elections prepared an electoral manifesto, which is composed of 18 pages. The party did not introduce any proposals or promises about tourism sector and this disinterest on tourism did not change when the elections were re-held on November, 2015.

\section{Discussion}

Table 2 presents the analysis of the plans and promises of the Turkish parties within the context of the sustainable tourism aims, prepared by the UNEP (2005). The analysis shows that the parties' policies and promises can be categorized into two clusters. The first cluster consists of promises on development and competition, including economic viability, physical integrity of touristic sites and conservation of environmental purity.

The analyzed Turkish political parties primarily call for the diversification of tourism in order to maintain economic viability. All parties, except the HDP that did not deal with tourism at all, deal with the importance of rural, winter and health tourism types. We should also note that all the three parties, namely the Ak Party, CHP and the MHP, introduce concrete projects and promises about the health tourism. This may lead us to conclude that health tourism in Turkey may take a step further in the near future.

Another promise of the political parties to ensure economic viability is to realize the tourism potential of the regions where touristic activities are not concentrated. For this, the parties promise to promote alternative tourism types in line with the natural, cultural or historical richness of these regions. Additionally, all the three parties deal with the importance of branding to maintain competitiveness of Turkish tourism. They consider tourism as an 
important opportunity to form and maintain foreign relations. Other promises of the three parties include the focus on high-income groups, extension of tourism throughout the year, stimulation of domestic demand, and promotion of the domestic tour operators.

The second cluster of the promises of Turkish parties, include employment quality to be maintained by improvement in education and service quality and the maintenance of local control through the participation of all stakeholders to the implementation of tourism policies. Conservation of physical integrity and environmental purity are the other promises of the Turkish parties. They all focus on the importance of the preparation of the environmental impact assessment reports according to scientific criteria and participation of the local stakeholders during the planning and implementation of tourism policies.

Turkish parties analyzed within the scope of this research view tourism as an important economic sector, whose potential negative effects on environment should be minimized. They primarily focus on the development of alternative tourism and place special focus on health tourism. They also share the belief that qualified labor force should be maintained through the improvements in education.

Although there are differences in the attitudes of the Turkish political parties towards the tourism sector, certain points shall be discussed within the context of the parties' promises and the development plans in Turkey. For instance, since the $5^{\text {th }}$ five-year development plan prepared in 1985, the issues of 'extension of tourism throughout the year', 'promotion of alternative tourism', and 'attracting high-income tourist groups' have been constantly repeated. Given the fact that the Turkish political parties continue to place emphasis on these issues in 2015, we may conclude that no success has been attained on these issues since 30 years.

There are also certain points that the individual parties may be criticized. As we stated above, the Ak Party, the ruling party since the 2002 elections, makes reference to the 2023 strategy paper and deals with the promises of tourism corridors, cities and ecotourism zones (Ak Party, 2015:235-236; Ministry Of Culture and Tourism, 2007:2). Given the fact that the 2023 strategy paper was prepared by the Ak Party government in 2007, we may conclude that the Ak Party has not been successful to attain these goals in the past 8 years. Another point to be criticized is the issue of tourism education. The 2023 strategy paper stated that tourism education should be based on the expectations of the sector and involve measurable results (Ministry Of Culture and Tourism, 2007:26) and that studies on general framework, strategies and content of tourism education should be conducted in line with the changes in tourism sector (Ministry Of Culture and Tourism, 2007:12). Given that the Ak Party continues to place emphasis on these goals in 2015 electoral program, we may argue that the party in government has been unsuccessful to realize these goals in the 8 years since the preparation of the strategy paper. However, we should also note that the problems about tourism education has been in the agenda of the state since the $2^{\text {nd }}$ five-year development plan (DPT, 1968). Despite nearly fifty years, the Turkish parties still promise to solve the problems of tourism education. In this sense, we may state that the Turkish politicians have not been successful to solve educational problems of the tourism sector for a half-century. 
Table 2: Analysis of the Promises of Turkish Political Parties According to the Sustainable Tourism Aims in 2015 Elections

\begin{tabular}{|c|c|c|c|c|}
\hline SUSTAINABLE & TOURISM AIMS & $\begin{array}{c}\text { AK } \\
\text { Party }\end{array}$ & CHP & MHP HDP \\
\hline $\begin{array}{l}\text { 1. Economic } \\
\text { Viability }\end{array}$ & $\begin{array}{l}\text { To ensure the viability and competitiveness } \\
\text { of tourism destinations and enterprises, so } \\
\text { that they are able to continue to prosper and } \\
\text { deliver benefits in the long term }\end{array}$ & + & + & + \\
\hline $\begin{array}{l}\text { 2. Local } \\
\text { Prosperity }\end{array}$ & $\begin{array}{l}\text { To maximize the contribution of tourism } \\
\text { to the economic prosperity of the host } \\
\text { destination, including the proportion of } \\
\text { visitor spending that is retained locally }\end{array}$ & & & + \\
\hline $\begin{array}{l}\text { 3a. } \\
\text { Employment } \\
\text { Quality }\end{array}$ & $\begin{array}{l}\text { To strengthen the number and quality of } \\
\text { local jobs created and supported by tourism, } \\
\text { including the level of pay, conditions of } \\
\text { service and availability to all without } \\
\text { discrimination by gender, race, disability or } \\
\text { in other ways }\end{array}$ & & + & \\
\hline $\begin{array}{l}\text { 3b. } \\
\text { Employment } \\
\text { Quality }\end{array}$ & $\begin{array}{l}\text { To improve tourism education and service } \\
\text { quality }\end{array}$ & + & + & + \\
\hline 4. Social Equity & $\begin{array}{l}\text { To seek a widespread and fair distribution } \\
\text { of economic and social benefits from } \\
\text { tourism throughout the recipient community, } \\
\text { including improving opportunities, income } \\
\text { and services available to the poor }\end{array}$ & & & + \\
\hline $\begin{array}{l}\text { 5.Visitor } \\
\text { Fulfilment }\end{array}$ & $\begin{array}{l}\text { To provide a safe, satisfying and fulfilling } \\
\text { experience for visitors, available to all } \\
\text { without discrimination by gender, race, } \\
\text { disability or in other ways }\end{array}$ & & + & \\
\hline $\begin{array}{l}\text { 6. Local } \\
\text { Control }\end{array}$ & $\begin{array}{l}\text { To engage and empower local communities } \\
\text { in planning and decision making about the } \\
\text { management and future development of } \\
\text { tourism in their area, in consultation with } \\
\text { other stakeholders }\end{array}$ & + & & \\
\hline $\begin{array}{l}7 \text { a. } \\
\text { Community } \\
\text { Wellbeing }\end{array}$ & $\begin{array}{l}\text { To maintain and strengthen the quality of } \\
\text { life in local communities, including social } \\
\text { structures and access to resources, amenities } \\
\text { and life support systems, avoiding any form } \\
\text { of social degradation or exploitation }\end{array}$ & & & + \\
\hline $\begin{array}{l}\text { 7b. Community } \\
\text { Wellbeing }\end{array}$ & To promote social tourism activities & & + & \\
\hline
\end{tabular}


Table 2 continued

\begin{tabular}{ll}
\hline $\begin{array}{l}\text { 8. Cultural } \\
\text { Richness }\end{array}$ & $\begin{array}{l}\text { To respect and enhance the historic } \\
\text { heritage, authentic culture, traditions and } \\
\text { distinctiveness of host communities }\end{array}$ \\
\hline $\begin{array}{l}\text { 9. Physical } \\
\text { Integrity }\end{array}$ & $\begin{array}{l}\text { To maintain and enhance the quality of } \\
\text { landscapes, both urban and rural, and avoid } \\
\text { the physical and visual degradation of the } \\
\text { environment }\end{array}$ \\
\hline 10. Biological & $\begin{array}{l}\text { To support the conservation of natural areas, } \\
\text { habitats and wildlife, and minimize damage } \\
\text { to them }\end{array}$ \\
\hline Diversity & $\begin{array}{l}\text { To minimize the use of scarce and non- } \\
\text { renewable resources in the development and } \\
\text { operation of tourism facilities and services }\end{array}$ \\
Efficiency & $\begin{array}{l}\text { To minimize the pollution of air, water and } \\
\text { land and the generation of waste by tourism } \\
\text { enterprises and visitors }\end{array}$ \\
\hline 12. & + \\
Environmental \\
Purity
\end{tabular}

We also believe that certain points deserve criticism in the electoral manifesto of the CHP. For instance, the party introduced concrete projects about the development of tourism in Izmir, the third largest Turkish province, which has been supporting the party since the 2002 elections. Although the party promises to turn Izmir into a health tourism center, we should also note that the center of Turkish health tourism is the province of Antalya (TÜRSAB, 2014). We believe that it would be more appropriate if the party introduces policies about the development of health tourism in this center. However, the party refrains to introduce any promises about this important tourism city. This raises doubts about the consistency of the party's promises. Finally, we should note that the MHP does not introduce any concrete projects about tourism sector, but only deals with its promises.

Another point we would like to add is the absence of any policies or promises of the Ak Party and the MHP about some of the dimensions of the sustainable tourism. For instance, despite the problems of the employees working in tourism sector presented by the Ministry of Labor and Social Security (ÇSGB, 2011), none of these parties bring any promises to improve the working conditions of the employees of the tourism enterprises. Rather, the two parties are concerned about the 'qualified labor force'. On the other hand, it is only the MHP, which is concerned about the maintenance of the social welfare while taking the life quality of the local inhabitations into consideration. Finally, all the three parties are indirectly concerned about the conservation of biological diversity.

Our analysis shows the disinterest of the HDP on tourism. Despite the fact that the party is the third party in parliament with its 59 seats, it did not deal with tourism at all (HDP, 2015). Given the fact that the party performed relatively well in tourism destinations, such as Istanbul (11 seats), Izmir (2 seats) and Antalya (1 seat) in 7 June elections, and that the party received the highest votes in Southeastern and Eastern Turkey, which have a rich potential 
for alternative tourism, the party refrains from brining any promises about tourism sector. We believe that this point deserves to be criticized for a party, which claims to transform from a single issue-party to a catch-all party.

\section{Conclusion}

Political parties are one of the primary actors of policy-making process, with their roles in setting the agenda, formation of governments and legislation. This work analyzed the electoral manifestos of the main Turkish parties, which participated in the two elections held in Turkey in 2015, in order to find out the attitudes and the promises of these parties towards the tourism sector. The study found that the Turkish parties are primarily concerned with the issues of the promotion of alternative tourism types in order to maintain economic development, the branding, promotion and marketing strategies, the promotion of new touristic zones and the conservation of the natural and cultural heritage while promoting the development of tourism. Besides, we found that the three Turkish parties were primarily concerned with the development of health tourism. All the Ak Party, CHP and the MHP introduce concrete projects and promises for the development of health tourism. Additionally, these parties promise to improve tourism education in line with the demands of the sector. We also found relatively less interest on the issues of improvement of employment opportunities, contribution of tourism to local social life and economy, conservation of the local culture and the biological diversity.

Overall, we may conclude that the Ak Party, CHP and the MHP propose tourism policies that consider the local and the global developments. In this sense, tourism for Turkish political parties is an important economic sector that should be regulated through the policy and strategy instruments. Further research may be carried out to assess the extent to which the parties in government realize the promises that they delivered, and to which the parties in opposition propose policies that they promised in 2015 elections. Such research may be useful to analyze whether the political parties deliver promises with populist concerns and to find out the existing and future problems of tourism sectors from the perspective of the politicians.

\section{REFERENCES}

AK Parti(2015a).7 Haziran 2015 Genel seçimleri seçim beyannamesi. Erişim Tarihi:02.06.2015, https://www.akparti.org.tr/site/haberler/secim-beyannamesi-aciklandi/73293\#1

AK Parti (2015b). 1 Kasım 2015 Genel seçimleri seçim beyannamesi. Erişim Tarihi: 10.11.2015, https://www.akparti.org.tr/site/haberler/secim-beyannamesi-aciklandi/73293\#1

Biçer, M. \& Yılmaz, H. H. (2009). Parlamentonun kamu politikası oluşturma ve planlama sürecindeki konumunun yeni kamu mali yönetim sistemi çerçevesinde değerlendirilmesi. Yasama Dergisi, 13, 124-163.

Chambers, D. \& Airey, D. (2001). Tourism policy in Jamaica: A tale of two governments. Current Issues in Tourism, 4(2/4), 94-120.

CHP (2015a). 7 Haziran 2015 Genel seçimleri seçim beyannamesi. Erişim Tarihi: 02.06.2015, http://yasanacakbirturkiye.com/CHP-SECIM-BILDIRGESI-2015.pdf

CHP (2015b). 1 Kasım 2015 Genel seçimleri seçim beyannamesi. Erişim Tarihi: 10.11.2015, https://www.chp.org.tr/Public\%5C1\%5CFolder/\%5C52608.pdf 
Çavuş, Ş., Ege, Z., \& Çolakoğlu, O. E. (2009). Türk turizm tarihi: Yapısal ve sektörel gelişim. İçinde Z. Ege, (ed.) Türkiye'de dış turizm talebinin yapısı ve gelişimi (ss. 35-56). Ankara: Detay Yayıncilık.

ÇSGB. (2011). Turizm sektöründe çalışma sürelerinin iyileştirilmesi programlı teftişi sonuç raporu. Erişim Tarihi: 05.08.2015, http://www.csgb.gov.tr/csgbPortal/ShowProperty/ WLP\%20Repository/itkb/dosyalar/yayinlar/yayinlar2013/2011_48

Demir, Ş. Ş. (2014). Beş yıllık kalkınma planlarından Türkiye turizm stratejisi 2023'e: turizmde tanıtma çalışmalarına yönelik içerik analizi. Uluslararası Avrasya Sosyal Bilimler Dergisi, 5(15), 101-119.

Diamond, L. \& Richard, G. (2001). Introduction in political parties and democracy. In L. Diamond, R. Gunther (Eds.), Baltimore And London (pp. ix-xxxiv), The Johns Hopkins University Press.

DPT (2015). 1963-2013 arasında yapılan beş yıllık kalkınma planları. Erişim Tarihi: 10.07.2015, http://www.kalkinma.gov.tr/Pages/KalkinmaPlanlari.aspx

Dredge, D., \& Jamal, T. (2015). Progress in tourism planning and policy: A post-structural perspective on knowledge production. Tourism Management, 51, 285-297.

Esen, Ş., Emir, G., \& Uyar, H. (2012). Cumhuriyet'ten günümüze hükümet programlarında turizm. Ankara: Detay Yayıncılık.

Gönenç, L. (2011). Siyasal partilerin seçim bildirgelerinde anayasa konusu: "Yol haritasi" de ğil, niyet beyani. Erişim Tarihi: 21.07.2015, http://www.tepav.org.tr/upload/ files/1306232876-0.Siyasal_Partilerin_Secim_Bildirgelerinde_Anayasa_Konusu_Yol_ Haritasi_Degil__Niyet_Beyani.pdf

Gürbüz, A., Demirkol, Ö., \& Yıldırım, M. (2014). Siyasi partilerin turizm algısı: 1950-1980 arası Türk siyasi parti programları ve seçim beyannamelerinde turizm olgusu. III. Disiplinlerarası Turizm Araştırmaları Kongresi, Kuşadası.

Hall, C. M. (2010). Politics and tourism - interdependency and implications in understanding change. In B. Richard, S. Wantanee (Eds.), Tourism and political change. Oxford: Goodfellow.

HDP (2015). 7 Haziran 2015 Genel seçimleri seçim beyannamesi. Erişim Tarihi: 02.06.2015, http://www.hdp.org.tr/images/UserFiles/Documents/Editor/HDP\%20 Se\%C3\%A7im\%20Bildirgesi\%20Tam\%20Metin.pdf

Inskeep, E. (1991). Tourism planning: An integrated and sustainable development approach. New York: John Wiley \& Sons.

İKSV. (2015). 2015 yılı seçim bildirgelerinin kültür politikalart perspektifinden de ğerlendirmesi. Erişim Tarihi: 21.07.2015, http://cdn.iksv.org/media/content/files/ secim_degerlendirme.pdf

Kilit, G., \& Çatır, B. (2015). Türkiye seçimlere ilerliyor: 7 Haziran'a doğru siyasi partilerin AB politikası. Erişim Tarihi: 21.07 .2015 , http://www.ikv.org.tr/ikv.asp?id=915

McLeod, M., \& Airey, D. (2007). The politics of tourism development: A case of dual governance in Tobago. International Journal of Tourism Policy, 1(3), 217 - 231. 
MHP (2015a). 7 Haziran 2015 Genel seçimleri seçim beyannamesi. Erişim Tarihi: 02.06.2015, http://www.mhp.org.tr/mhp_index.php

MHP (2015b). 1 Kasım 2015 Genel seçimleri seçim beyannamesi. Erişim Tarihi: 10.11.2015, https://www.mhp.org.tr/usr_img/mhpweb/1kasimsecimleri/beyanname_1kasim2015. pdf

Oğurlu, E. (2011). Approaches of the political parties in Turkey on the issues of the foreign policy and the European Union in their election manifesto towards the June 2011 elections. IKV Journal, 163, 15-21.

Özbudun, E. (1968). Batı demokrasilerinde ve Türkiye'de parti disiplini. Ankara: Başnur Matbaas1.

Sarkım, M. (2008). Değişen seyahat ĕ̆ilimleri kapsamında sürdürülebilir turizm anlayışının turizm politikaları üzerine etkileri. II. Ulusal İktisat Kongresi, İzmir.

Sözen, Ö. M. (2006). 1982 sonrası dönemde Türkiye'de uygulanan turizm politikaları ve turizm politikalarının Çanakkale ekonomisine etkileri. Yayınlanmamış Yüksek Lisans Tezi. Çanakkale On Sekiz Mart Üniversitesi/Sosyal Bilimler Enstitüsü, Çanakkale.

Stratejik Düşünce Enstitüsü. (2011). Siyasi partilerin seçim beyannameleri üzerine bir karşılaştırma. Erişim Tarihi: 21.07.2015, http://www.sde.org.tr/Files/Reports/ d74861ce610fad97.pdf

Strom, K., \& Müller, W. C. (2009). Parliamentary democracy, agency problems, and party politics. In G. Daniela, B. Kenneth (Eds.), Intra-party politics and coalition governments in parliamentary democracies (pp. 25-49). London: Routledge.

T.C. Kalkınma Bakanlığı. (2015). Turizm özel ihtisas komisyonu raporu. Erişim Tarihi: 23.07.2015, http://www.cka.org.tr/dosyalar/Ozel\%20Ihtisas\%20Komisyonu\%20 Raporlar\%C4\%B1/TUR\%C4\%B0ZM\%20\%C3\%96\%C4\%B0K.pdf

T.C. Kültür ve Turizm Bakanlığı. (2007). 2023 Türkiye turizm stratejisi. Erişim Tarihi: 10.07. 2015, http://www.daka.org.tr/panel/files/files/belgeler/planlama/turkiye_turizm.pdf

Tok, N. T. (2012). Türkiye'deki siyasal partilerin eğitim söylemleri ve siyasaları. Kuram ve Uygulamada Ĕ̈itim Yönetimi, 18(2), 273-312.

Toker, B. (2007). Türkiye'de turizm sektörü teşviklerinin değerlendirilmesi. Yönetim ve Ekonomi, 14(2), 81-92.

TURSAB (2014). Sa ğlık turizmi raporu. Erişim Tarihi: 03.08.2015, http://www.tursab.org.tr/ dosya/12186/saglikturizmiraporu_12186_5485299.pdf

UNEP (2005). Making tourism more sustainable: a guide for policy makers. Erişim Tarihi: 23.07.2015, http://www.Unep.Fr/Shared/Publications/pdf/DTIx0592xPATourismPolicyEN.pdf

Yüksel, A., Çulha, O., \& Yüksel, F. (2009). Siyasi partiler gözüyle turizm. Seyahat Ve Otel İsletmeciliği Dergisi, 6(3), 78-81.

Yüksel, A., Çulha, O., Epik, F., \& Efendi, E. (2009). Turizm bakanları ve söylemleri: Türkiye'nin turizm politikası. Seyahat Ve Otel İsletmeciliği Dergisi, 6(4), 6-25. 